\title{
Mannitol 1-phosphate mediates an inhibitory effect of mannitol on the activity and the translocation of glucokinase in isolated rat hepatocytes
}

\author{
L. Niculescu, E. Van Schaftingen \\ Laboratoire de Chimie Physiologique, ICP and Université Catholique de Louvain, Brussels, Belgium
}

\begin{abstract}
Summary When tested in the presence of an inhibitor of sorbitol dehydrogenase, both mannitol and sorbitol caused a progressive inhibition of the detritiation of $\left[2-{ }^{3} \mathrm{H}\right]$ glucose in isolated rat hepatocytes. The purpose of the present work was to investigate the possiblity that this effect was mediated by the regulatory protein of glucokinase. When added to hepatocytes, mannitol decreased the apparent affinity of glucokinase for glucose and increased the concentration of fructose required to stimulate detritiation, without affecting the concentration of fructose 1-phosphate. Its effect could be attributed to the formation of mannitol 1-phosphate, a potent agonist of the regulatory protein, which, similarly to fructose 6-phosphate, reinforces its inhibitory action. Formation of mannitol 1-phosphate in hepatocytes was dependent on the presence of mannitol and was stimulated by compounds that increase the concentration of glucose 6-
\end{abstract}

phosphate. Liver extracts catalysed the conversion of mannitol to mannitol 1-phosphate about 7 times more rapidly in the presence of glucose 6-phosphate than of ATP. The glucose 6-phosphate-dependent formation was entirely accounted for by a microsomal enzyme, glucose-6-phosphatase and was not due to a loss of latency of this enzyme. In hepatocytes in primary culture, mannitol decreased the detritiation rate and counteracted the effect of fructose to stimulate glucokinase translocation. Taken together, these results strongly support a central role played by the regulatory protein in the control of glucokinase activity and translocation in the liver, as well as a feedback control exerted by fructose 6-phosphate on this enzyme. [Diabetologia (1998) 41: 947-954]

Keywords Glucokinase, glucose-6-phosphatase, mannitol, mannitol 1-phosphate, nuclear protein
Glucokinase, the enzyme catalysing glucose phosphorylation in the liver and in pancreatic islets, plays a central role in blood glucose homeostasis [1-3]. In the liver, its activity is not only modulated by the concentration of its hexose-substrate but also by a regulatory protein that binds and inhibits glucokinase competitively with respect to glucose. In mammals, the action of the regulatory protein is reinforced by fructose 6-phosphate and its analogues sorbitol 6phosphate and mannitol 1-phosphate, and suppressed by fructose 1-phosphate [4]. The regulatory protein

Received: 4 February 1998 and in revised form: 31 March 1998

Corresponding author: Dr. E. Van Schaftingen, Laboratoire de Chimie Physiologique, UCL 75.39, Avenue Hippocrate 75, B-1200 Brussels, Belgium accounts for the fact that glucokinase activity, as measured by the detritiation of $\left[2-{ }^{3} \mathrm{H}\right]$ glucose, increases in rat hepatocytes in response to fructose or other agents (sorbitol, D-glyceraldehyde) that give rise to fructose 1-phosphate [5]. The regulatory protein should also mediate an inhibitory effect of fructose 6-phosphate on the phosphorylation of glucose but this inhibitory effect is difficult to demonstrate. This is because glucose-6-phosphatase catalyses an exchange reaction between glucose and glucose 6-phosphate, which partly accounts for the detritiation of $\left[2-{ }^{3} \mathrm{H}\right]$ glucose and which intensifies when the concentration of hexose 6-phosphates increases, masking therefore the reinforcement of the inhibition by the regulatory protein [6].

Recent work indicates that glucokinase is present in the nucleus of hepatocytes incubated in the pres- 
ence of a low concentration of glucose and that it migrates to the cytosol in response to an increase in the concentration of this sugar or to the addition of agents (fructose, sorbitol, glyceraldehyde) giving rise to fructose 1-phosphate [7-12]. In contrast, the regulatory protein appears to remain in the nucleus under these conditions $[11,13]$. These observations suggest that the regulatory protein plays the role of a nuclear anchor for glucokinase. Due to its effect on the regulatory protein, fructose 6-phosphate could also be expected to participate in the control of glucokinase translocation but the difficulty of modifying its concentration independently of that of fructose 1-phosphate has, up to now, hindered experiments to show this participation.

We recently observed that, when tested in the presence of SDI 158 (an inhibitor of sorbitol dehydrogenase [14] that efficiently blocks the formation of fructose 1-phosphate from sorbitol [12]) both sorbitol and mannitol inhibited detritiation of $\left[2-{ }^{3} \mathrm{H}\right] \mathrm{glu}-$ cose in isolated rat hepatocytes. A potential explanation for these effects is that they are mediated by sorbitol 6-phosphate and mannitol 1-phosphate acting by binding to the regulatory protein of glucokinase. The purpose of the present work was to investigate this hypothesis.

\section{Materials and methods}

Materials. Mannitol ("for biochemistry" grade) was from Merck (Darmstadt, Germany). SDI 158 [2-hydroxymethyl-4(4-N,N-dimethylamino-1-piperazino) pyrimidine] was a kind gift of Dr. Geisen (Hoechst, Frankfurt/Main, Germany). Collagenase and auxiliary enzymes were from Boehringer (Mannheim, Germany). Mannitol 1-phosphate dehydrogenase was purified from E. coli as described by Klungsøyr [15]. The sources of other materials were as described previously [12].

Isolation and incubation of hepatocytes. Hepatocytes were isolated from the liver of fed male Wistar rats weighing 300-340 $\mathrm{g}$, by a modification [16] of the method of Seglen [17]. The cells were resuspended in a Krebs-Henseleit bicarbonate buffer at a final concentration of $10-16 \mathrm{~g}$ protein/l. Aliquots $(2 \mathrm{ml})$ of this suspension were incubated at $37^{\circ} \mathrm{C}$ in $20 \mathrm{ml}$ vials equilibrated with a $95 \% \mathrm{O}_{2}-5 \% \mathrm{CO}_{2}$ gas phase. The substrates were added after a preincubation of 10-20 $\mathrm{min}$ in the presence of $5 \mathrm{mmol} / \mathrm{l}$ glucose.

The incubations were stopped at the indicated times by mixing $1 \mathrm{ml}$ of the cell suspension with $0.5 \mathrm{ml} 10 \%$ perchloric acid and the resulting extracts were used for the measurement of ${ }^{3} \mathrm{H}_{2} \mathrm{O}$ [18], fructose 1-phosphate [19] and mannitol 1-phosphate [20]. For the assays of hexose 6-phosphates (glucose 6phosphate + fructose 6-phosphate, which were always found to be close to their thermodynamic, $3 / 1$, equilibrium) [21], the cells were separated from the medium by centrifugation in tubes containing $0.5 \mathrm{ml}$ silicone oil on top of $0.5 \mathrm{ml} 10 \%(\mathrm{w} / \mathrm{v})$ perchloric acid [22].

For the experiments shown in Figure 9, hepatocytes were cultured and glucokinase translocation was measured as previously described [7, 12].
Partial purification and assay of phosphoglucose isomerase. For the partial purification of phosphoglucose isomerase, the liver of one rat was homogenised in 2 volumes of a medium containing $20 \mathrm{mmol} / \mathrm{l}$ HEPES, pH 7.1, $100 \mathrm{mmol} / \mathrm{l} \mathrm{KCl}$, $1 \mathrm{mmol} / \mathrm{l}$ dithiothreitol, $10 \mathrm{mg} / \mathrm{l}$ leupeptin and $10 \mathrm{mg} / \mathrm{l}$ antipain. The homogenate was centrifuged for $10 \mathrm{~min}$ at $10000 \times \mathrm{g}$ and the resulting extract $(25 \mathrm{ml})$ was used to prepare a 5-20\% poly(ethyleneglycol) 6000 fraction [5]. This fraction was resuspended in $8 \mathrm{ml}$ of $20 \mathrm{mmol} / 1$ HEPES pH 6.2 containing $1 \mathrm{mmol} / \mathrm{l}$ dithiothreitol and $10 \mathrm{mg} / \mathrm{l}$ leupeptin and antipain, and applied onto a column $(1.6 \times 15 \mathrm{~cm})$ of SP-Sepharose Fast-Flow equilibrated in the same buffer. Protein was eluted by application of a $0-500 \mathrm{mmol} / \mathrm{l} \mathrm{KCl}$ gradient in the same buffer. The most active fractions were used to study the kinetic properties. The enzyme was purified about 100 -fold compared to the initial extract and the yield was about $25 \%$.

Phosphoglucose isomerase was assayed spectrophotometrically at $30^{\circ} \mathrm{C}$ in a mixture $(1 \mathrm{ml})$ containing $50 \mathrm{mmol} / 1$ Tris$\mathrm{HCl}, \mathrm{pH} 7.8,50 \mathrm{mmol} / \mathrm{l} \mathrm{KCl}, 5 \mathrm{mmol} / \mathrm{l} \mathrm{MgCl}_{2}, 0.5 \mathrm{mmol} / \mathrm{l}$ fructose 6-phosphate, $0.6 \mathrm{mmol} / \mathrm{l} \mathrm{NAD}^{+}$and $5 \mathrm{mg} / 1$ glucose 6phosphate dehydrogenase from Leuconostoc mesenteroides.

Study of the formation of mannitol 1-phosphate in cell-free extracts. The livers from fed rats were homogenised with 3 volumes of an ice-cold medium containing $25 \mathrm{mmol} / \mathrm{l} \mathrm{HEPES}$, $\mathrm{pH} 7.1,25 \mathrm{mmol} / 1 \mathrm{KCl}, 0.25 \mathrm{~mol} / \mathrm{l}$ sucrose, $10 \mathrm{mg} / \mathrm{l}$ antipain and $10 \mathrm{mg} / \mathrm{l}$ leupeptin in a Potter-Elvehjem apparatus and the homogenate was centrifuged for $10 \mathrm{~min}$ at $11000 \times g$. The resulting supernatant (extract) was centrifuged at $50000 \times g$ for $45 \mathrm{~min}$; the high-speed supernatant was removed and the microsomal pellet was resuspended in a volume of homogenisation buffer equal to that of the supernatant. Washed microsomes were obtained by recentrifuging the latter fraction and resuspending it in fresh medium. Incubations were started by adding $300 \mu \mathrm{l}$ of liver extract, high-speed supernatant or pellet to an incubation mixture containing $50 \mathrm{mmol} / \mathrm{l}$ HEPES $\mathrm{pH} 7.1$ and the indicated concentrations of mannitol, glucose 6-phosphate or glycerol 3-phosphate in a final volume of $3 \mathrm{ml}$. At different times (usually 5, 10, 20 and $40 \mathrm{~min}$ ), samples were mixed with $0.5 \mathrm{vol} 10 \%$ (w/v) perchloric acid and centrifuged; the supernatant was neutralized with $\mathrm{K}_{2} \mathrm{CO}_{3}$ and used for the assay of mannitol 1-phosphate or hexose 6-phosphates.

Statistical analyses. These were performed using Student's $t$ test for paired data. Note that in some figures, SEM values are not visible because they are smaller than the size of the symbols.

\section{Results}

Inhibitory effects of mannitol and sorbitol on the detritiation of $\left[2-{ }^{3} \mathrm{H}\right]$ glucose. We previously showed that commercial mannitol is contaminated by about $1 \%$ sorbitol, which is converted to fructose and fructose 1-phosphate and, therefore, stimulates glucokinase activity in isolated hepatocytes [12]. This effect can be prevented by the addition of SDI 158, a powerful inhibitor of sorbitol dehydrogenase [14]. When tested under this condition, both sorbitol and mannitol at a concentration of $30 \mathrm{mmol} / \mathrm{l}$ caused a progressive inhibition of glucose detritiation, which decreased to about $30-40 \%$ of the control value after $55 \mathrm{~min}$ (Fig.1). The polyols exerted a half-maximal effect at 


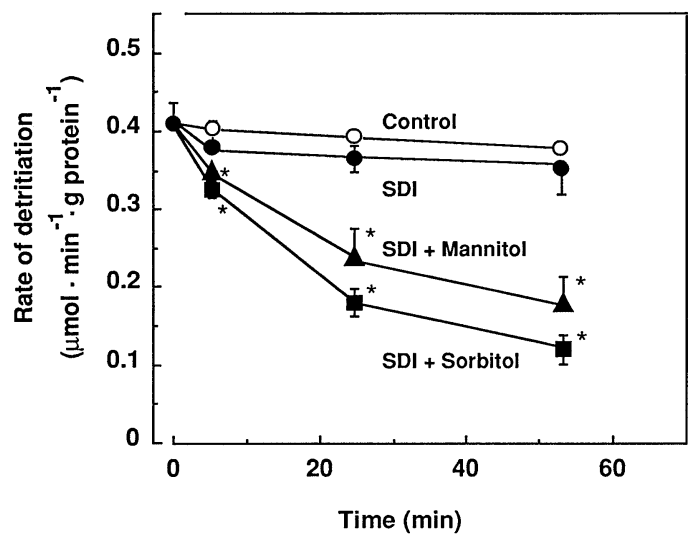

Fig. 1. Time-course of the effect of mannitol and sorbitol on the rate of detritiation of $\left[2-{ }^{3} \mathrm{H}\right]$ glucose in isolated hepatocytes. Suspensions of hepatocytes were preincubated for $20 \mathrm{~min}$ in the presence of $5 \mathrm{mmol} / \mathrm{l}$ glucose with (closed symbols) or without (open symbol) $1 \mathrm{mmol} / \mathrm{l} \mathrm{SDI} 158$ before addition of $30 \mathrm{mmol} / \mathrm{l}$ mannitol $(\boldsymbol{\Delta})$ or sorbitol $(\boldsymbol{\square}) \cdot\left[2-{ }^{3} \mathrm{H}\right]$ Glucose was added at various times after this addition and the incubations arrested 10 min later. Results are means \pm SEM for 4 experimental values. * different from control with $1 \mathrm{mmol} / \mathrm{l} \mathrm{SDI}$ $158(p<0.05)$

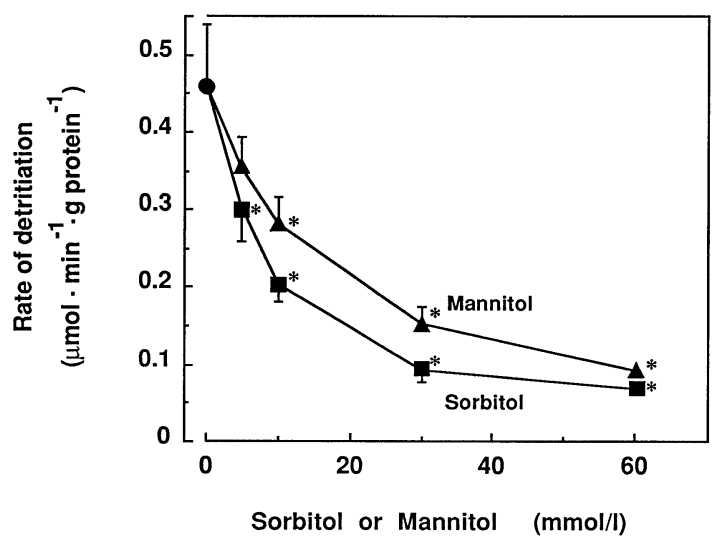

Fig. 2. Effect of the concentration of mannitol and sorbitol on the rate of detritiation of $\left[2-{ }^{3} \mathrm{H}\right]$ glucose in hepatocytes incubated in the presence of SDI 158. Suspensions of hepatocytes were preincubated for $10 \mathrm{~min}$ in the presence of $5 \mathrm{mmol} / \mathrm{l} \mathrm{glu}$ cose and $1 \mathrm{mmol} / 1$ SDI 158 before addition of the indicated concentrations of polyol. $\left[2-{ }^{3} \mathrm{H}\right]$ Glucose was added $30 \mathrm{~min}$ later and the incubations arrested $10 \mathrm{~min}$ after this last addition. Results are means \pm SEM for 4 experimental values. * different from control without polyol $(p<0.05)$

concentrations of 7 and $10 \mathrm{mmol} / \mathrm{l}$, respectively (Fig. 2).

The effect of mannitol was further investigated in the following experiments. Detritiation was measured at different concentrations of glucose to determine the type of inhibition exerted by the polyol on glucokinase. As is apparent in Figure 3, the inhibitory effect of $30 \mathrm{mmol} / \mathrm{l}$ mannitol decreased from a value of about $45 \%$ at $5 \mathrm{mmol} / \mathrm{l}$ glucose to about $20 \%$ in the presence of $100 \mathrm{mmol} / \mathrm{l}$ of this hexose, suggesting that the polyol decreased the apparent affinity of glu-

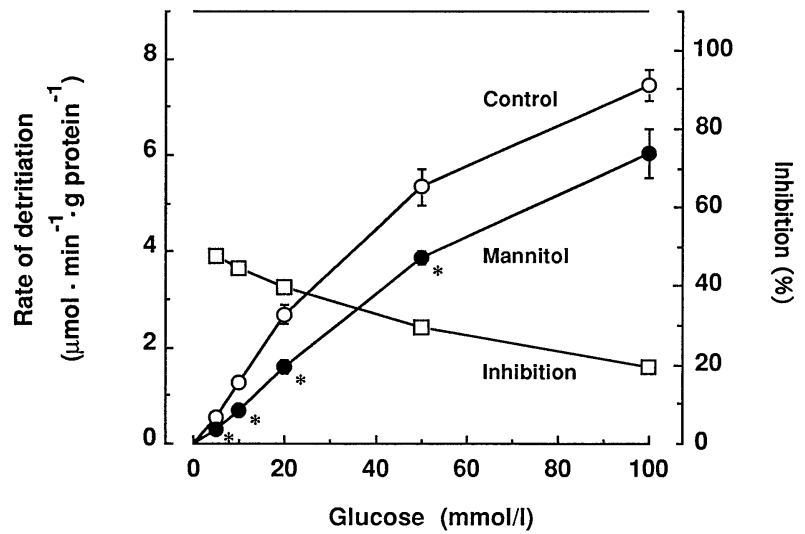

Fig. 3. Effect of the concentration of glucose on the rate of detritiation of $\left[2-{ }^{3} \mathrm{H}\right]$ glucose in hepatocytes incubated with or without mannitol. Hepatocytes were incubated with $5 \mathrm{mmol} / \mathrm{l}$ glucose and $1 \mathrm{mmol} / \mathrm{l} \mathrm{SDI}-158$ for $10 \mathrm{~min}$ before addition of $30 \mathrm{mmol} / \mathrm{l}$ mannitol. $\left[2-{ }^{3} \mathrm{H}\right]$ glucose was added $30 \mathrm{~min}$ later together with cold glucose to reach the concentrations indicated. The incubations were arrested $10 \mathrm{~min}$ after these last additions. Results are means \pm SEM for 4 experimental values. * different from control without mannitol $(p<0.05)$. The inhibition exerted by mannitol is also presented

cokinase for glucose. The data shown in Figure 3 also suggest that mannitol decreased somewhat the Vmax of detritiation.

Since the change in affinity for glucose could be due to an increase in the inhibition exerted by the regulatory protein, we tested the effect of different concentrations of fructose both in the absence and in the presence of mannitol (Fig.4). The ketose stimulated detritiation under both conditions but, remarkably, more fructose was needed to reach a half-maximal effect in the presence of mannitol than in its absence (Fig. 4A) despite the fact that the fructose 1phosphate concentrations were comparable under both conditions (Fig. 4B). The inhibition exerted by mannitol decreased from about $50 \%$ in the absence of fructose to about $15 \%$ in the presence of $500 \mu \mathrm{mol} / 1$ fructose, indicating that the ketose counteracted the effect of mannitol to a large extent, though not completely.

Presence of mannitol 1-phosphate in cells incubated with mannitol. The results described above suggested that the effect of the regulatory protein in cells incubated with mannitol was reinforced by a compound that counteracted the effect of fructose 1-phosphate. A potential mediator was mannitol 1-phosphate, which, as mentioned above, has fructose 6-phosphate-like effects on the purified regulatory protein [23]. Using a specific enzymatic assay [20], we found that the addition of mannitol to hepatocytes resulted in the appearance of mannitol 1-phosphate in the cells (Fig.5). This formation was not significantly affected by SDI 158. From the data shown in Figure 5, and assuming that the intracellular water amounts to 


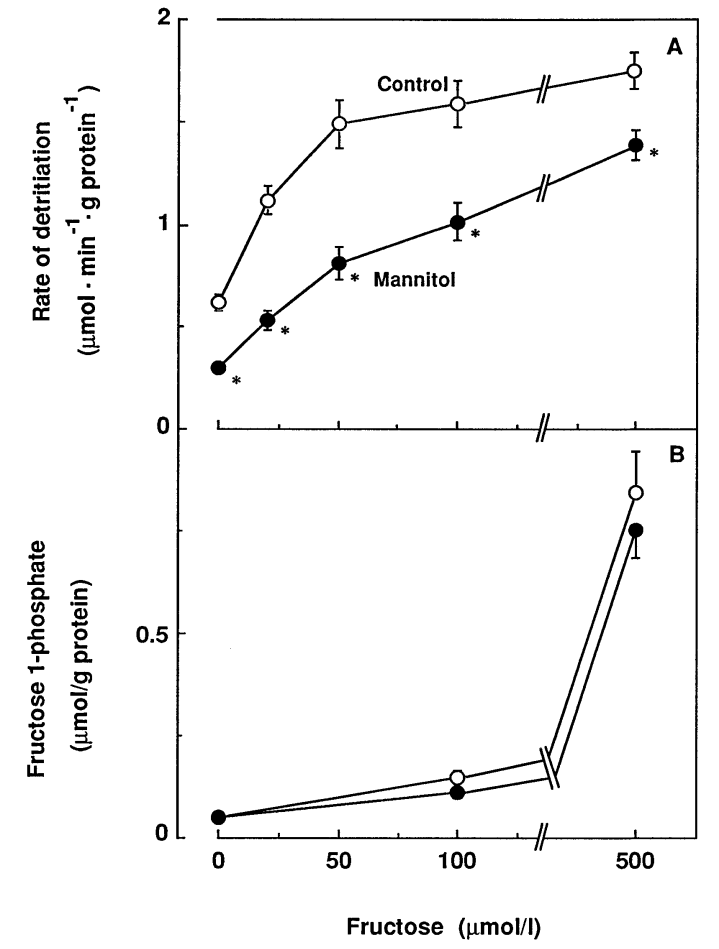

Fig.4. Effect of the concentration of fructose on the rate of detritiation of $\left[2-{ }^{3} \mathrm{H}\right]$ glucose and on the concentration of fructose 1-phosphate in hepatocytes incubated with or without mannitol. Hepatocytes were incubated with $5 \mathrm{mmol} / \mathrm{l}$ glucose and $1 \mathrm{mmol} / \mathrm{l} \mathrm{SDI}-158$. Mannitol $(30 \mathrm{mmol} / \mathrm{l})$ was added after $10 \mathrm{~min}$, fructose after $30 \mathrm{~min}$ and $\left[2-{ }^{3} \mathrm{H}\right]$ glucose after $40 \mathrm{~min}$. The incubations were arrested after $55 \mathrm{~min}$. Results are means \pm SEM for 4 experimental values. * different from control without mannitol $(p<0.05)$

$2 \mathrm{ml} / \mathrm{g}$ protein [6], we calculated that the mannitol 1phosphate concentration reached 70 and $125 \mu \mathrm{mol} / \mathrm{l}$ after $40 \mathrm{~min}$ in the presence of 30 and $60 \mathrm{mmol} / \mathrm{l} \mathrm{man}-$ nitol, respectively.

Mechanism of the formation of mannitol 1-phosphate. To identify the enzyme responsible for the phosphorylation of mannitol, we measured the formation of mannitol 1-phosphate in hepatocytes incubated with saturating concentrations of the substrates of glucokinase, fructokinase and triokinase. We also tested the effects of sorbitol and of glucosamine, an inhibitor of glucokinase (Fig. 6, Table 1). Figure 6 shows that the mannitol 1-phosphate concentration increased progressively with time following mannitol addition, the initial rate of formation being $0.02 \mu \mathrm{mol} \cdot \mathrm{min}^{-1} \cdot \mathrm{g}$ protein $^{-1}$ in the presence of $5 \mathrm{mmol} / \mathrm{l}$ glucose and $0.035 \mu \mathrm{mol} \cdot \mathrm{min}^{-1} \cdot \mathrm{g}$ protein $^{-1}$ in the presence of $50 \mathrm{mmol} / 1$ glucose or in the presence of $5 \mathrm{mmol} / 1 \mathrm{glu}-$ cose together with $20 \mathrm{mmol} / \mathrm{l}$ dihydroxyacetone. Remarkably, glucose, fructose and dihydroxyacetone did not inhibit but, rather, they increased the formation of mannitol 1-phosphate, whereas glucosamine had the opposite effect (Table 1). These results excluded the possibility that one of the kinases men-

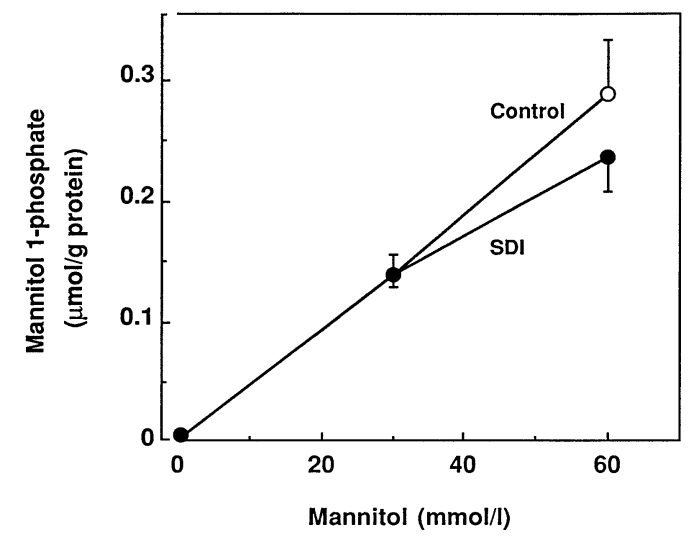

Fig. 5. Effect of the concentration of mannitol and of SDI 158 on the formation of mannitol 1-phosphate in isolated hepatocytes. Hepatocytes were incubated for $40 \mathrm{~min}$ with $5 \mathrm{mmol} / \mathrm{l}$ glucose in the presence or in the absence of $1 \mathrm{mmol} / \mathrm{l} \mathrm{SDI} 158$ and of the indicated concentrations of mannitol. Results are the means \pm SEM for 4 experimental values. No difference between both conditions $(p>0.05)$

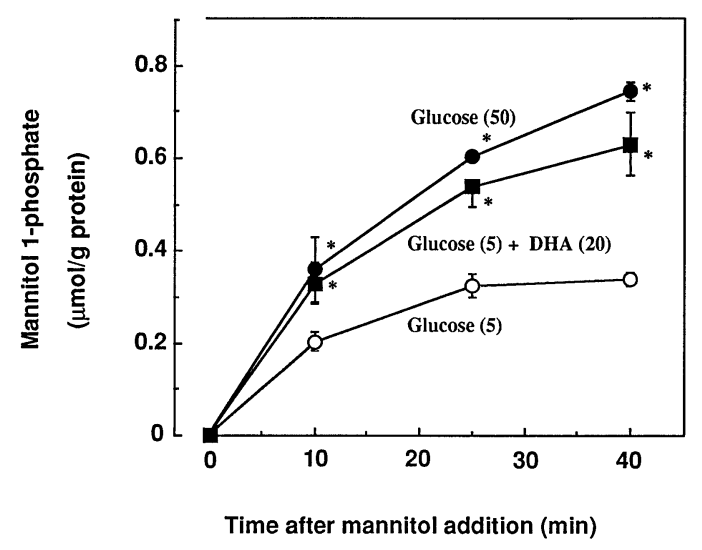

Fig. 6. Effect of glucose and dihydroxyacetone on the formation of mannitol 1-phosphate in hepatocytes incubated in the presence of mannitol. Hepatocytes were preincubated for $10 \mathrm{~min}$ with $5 \mathrm{mmol} / \mathrm{l}$ glucose before addition of $60 \mathrm{mmol} / \mathrm{l}$ mannitol with or without $20 \mathrm{mmol} / \mathrm{l}$ dihydroxyacetone or $45 \mathrm{mmol} / \mathrm{l}$ glucose. The incubations were arrested at the indicated times after these additions. Results are the means \pm SEM for 4 experimental values. * different from control with $5 \mathrm{mmol} / \mathrm{l}$ glucose $(p<0.05)$

tioned above was responsible for the formation of mannitol 1-phosphate.

Another enzyme that could be responsible for the formation of mannitol 1-phosphate is glucose-6-phosphatase. This enzyme is indeed able to transfer a phosphoryl group to various acceptors, including glucose, mannitol and sorbitol [24]. Its $\mathrm{K}_{\mathrm{m}}$ for glucose 6phosphate $(2 \mathrm{mmol} / \mathrm{l}$ according to [25]) is higher than the concentration of this phosphate ester in liver cells and its activity is therefore almost proportional to the concentration of this substrate. We measured the concentration of hexose 6-phosphates (sum of glucose 6-phosphate and fructose 6-phosphate, which are maintained close to their thermodynamic equilib- 
Table 1. Concentrations of mannitol 1-phosphate and hexose 6-phosphates in hepatocytes incubated in the presence of $60 \mathrm{mmol} / \mathrm{l}$ mannitol and different substrates

\begin{tabular}{|c|c|c|}
\hline Substrate & Mannitol 1-phosphate & Hexose 6-phosphates \\
\hline $5 \mathrm{mmol} / 1$ glucose & $0.49 \pm 0.03$ & $0.66 \pm 0.06$ \\
\hline $50 \mathrm{mmol} / \mathrm{l}$ glucose & $1.08 \pm 0.06^{\mathrm{a}}$ & $1.75 \pm 0.06^{\mathrm{a}}$ \\
\hline $5 \mathrm{mmol} / \mathrm{l}$ glucose $+20 \mathrm{mmol} / \mathrm{l}$ glucosamine & $0.39 \pm 0.06^{\mathrm{a}}$ & $0.38 \pm 0.04^{\mathrm{a}}$ \\
\hline $5 \mathrm{mmol} / \mathrm{l}$ glucose $+2 \mathrm{mmol} / \mathrm{l}$ fructose & $0.71 \pm 0.07^{\mathrm{a}}$ & $0.77 \pm 0.06$ \\
\hline $5 \mathrm{mmol} / \mathrm{l}$ glucose $+5 \mathrm{mmol} / \mathrm{l}$ fructose & $0.96 \pm 0.09^{\mathrm{a}}$ & $0.97 \pm 0.05^{\mathrm{a}}$ \\
\hline $5 \mathrm{mmol} / \mathrm{l}$ glucose $+5 \mathrm{mmol} / \mathrm{l}$ sorbitol & $0.97 \pm 0.09^{\mathrm{a}}$ & $1.09 \pm 0.06^{\mathrm{a}}$ \\
\hline $5 \mathrm{mmol} / \mathrm{l}$ glucose $+10 \mathrm{mmol} / \mathrm{l}$ dihydroxyacetone & $0.93 \pm 0.08^{\mathrm{a}}$ & $1.24 \pm 0.19^{\mathrm{a}}$ \\
\hline $5 \mathrm{mmol} / 1$ glucose $+20 \mathrm{mmol} / 1$ dihydroxyacetone & $1.13 \pm 0.12^{\mathrm{a}}$ & $1.63 \pm 0.13^{\mathrm{a}}$ \\
\hline
\end{tabular}

The cells were incubated for $10 \mathrm{~min}$ with $5 \mathrm{mmol} / \mathrm{l}$ glucose before addition of mannitol either alone or with the indicated substrates. The incubations were arrested 40 min later. Results are expressed in $\mu \mathrm{mol} / \mathrm{g}$ protein and are means \pm SEM for $n=5$ observations.

${ }^{\text {a }}$ different from control with $5 \mathrm{mmol} / \mathrm{l}$ glucose $(p<0.05)$

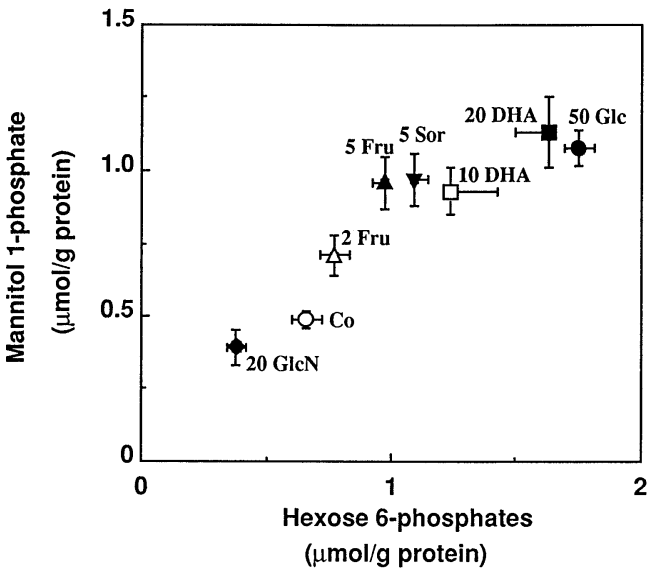

Fig.7. Correlation between the concentrations of mannitol 1phosphate and hexose 6-phosphates in hepatocytes incubated in the presence of $60 \mathrm{mmol} / \mathrm{l}$ mannitol and different substrates. Same results as in Table $1 . \mathrm{Co}$ : Control ( $5 \mathrm{mmol} / \mathrm{l}$ glucose); Fru: fructose; GlcN: glucosamine; Glc: glucose; Sor: sorbitol; DHA: dihydroxyacetone

rium) in the experiment shown in Table 1 and found that there was indeed a direct relationship between the concentration of mannitol 1-phosphate and that of hexose 6-phosphates under all tested conditions (Fig. 7).

Formation of mannitol 1-phosphate in cell-free systems. When incubated with $200 \mathrm{mmol} / \mathrm{l}$ mannitol, rat liver extracts catalysed the formation of mannitol 1phosphate at rates of $0.180 \pm 0.036$ and $0.026 \pm 0.003$ $(n=3) \mu \mathrm{mol} \cdot \mathrm{min}^{-1} \cdot \mathrm{g}$ protein ${ }^{-1}$ protein in the presence of $10 \mathrm{mmol} / \mathrm{l}$ glucose 6 -phosphate or $10 \mathrm{mmol} / \mathrm{l}$ ATP-Mg, respectively, the rate being much lower $\left(0.007 \pm 0.003 \mu \mathrm{mol} \cdot \mathrm{min}^{-1} \cdot \mathrm{g}\right.$ protein ${ }^{-1}$ protein $)$ in the absence of phosphate donor. After high-speed centrifugation of the extract, all glucose 6-phosphate-dependent activity was recovered in the microsomal pellet and none in the supernatant.

As shown in Figure 8, formation of mannitol 1phosphate in washed microsomes was about 5 times more rapid with glucose 6-phosphate than with man- nose 6-phosphate, and Pi formation about 10 times more rapid, indicating that the microsomes were latent [26]. As expected, deoxycholate stimulated mannose 6-phosphate hydrolysis, which became then comparable to glucose 6-phosphate hydrolysis. It also stimulated the mannitol 1-phosphate formation from glucose 6-phosphate and mannose 6-phosphate by about 4 and 20 -fold, respectively.

Other experiments (not shown) showed that the formation of mannitol 1-phosphate with glucose 6phosphate as phosphoryl donor was proportional to the concentration of mannitol, up to $200 \mathrm{mmol} / \mathrm{l}$, and that it was inhibited by about $50 \%$ with $200 \mathrm{mmol} / \mathrm{l}$ glucose. Furthermore, the formation of mannitol 1phosphate was inhibited when the microsomes had been preincubated at $\mathrm{pH} 5$ for $10 \mathrm{~min}$ at $37^{\circ} \mathrm{C}$, a treatment known to inactivate glucose-6-phosphatase [27] or when vanadate, an inhibitor of this enzyme [28], was included in the assays (not shown).

Effect of mannitol on the translocation of glucokinase. It was of interest to check the effect of mannitol on the translocation of glucokinase. Since these experiments are best performed on hepatocytes in primary culture [7], we first verified that mannitol inhibited detritiation in this type of preparation. About $50 \%$ inhibition was observed with cells incubated for $2 \mathrm{~h}$ with $30 \mathrm{mmol} / \mathrm{l}$ mannitol and $1 \mathrm{mmol} / \mathrm{l} \mathrm{SDI} 158$ in the presence of $5 \mathrm{mmol} / \mathrm{l}$ glucose (not shown).

As shown in Figure 9, preincubation of the cells with $30 \mathrm{mmol} / \mathrm{l} \mathrm{mannitol} \mathrm{did} \mathrm{not} \mathrm{significantly} \mathrm{change}$ the basal and maximal degrees of translocation but increased severalfold the concentration of fructose required to observe intermediate effects.

Effect of mannitol 1-phosphate on the kinetics of phosphoglucose isomerase. Since phosphoglucose isomerase is responsible for the release of tritium from $\left[2-{ }^{3} \mathrm{H}\right]$ glucose 6-phosphate [29], we tested the effect of mannitol 1-phosphate, a fructose 6-phosphate analogue, on the activity of this enzyme. Partially purified rat liver phosphoglucose isomerase displayed a $\mathrm{Km}$ of $0.05 \mathrm{mmol} / \mathrm{l}$ for fructose 6-phosphate; 


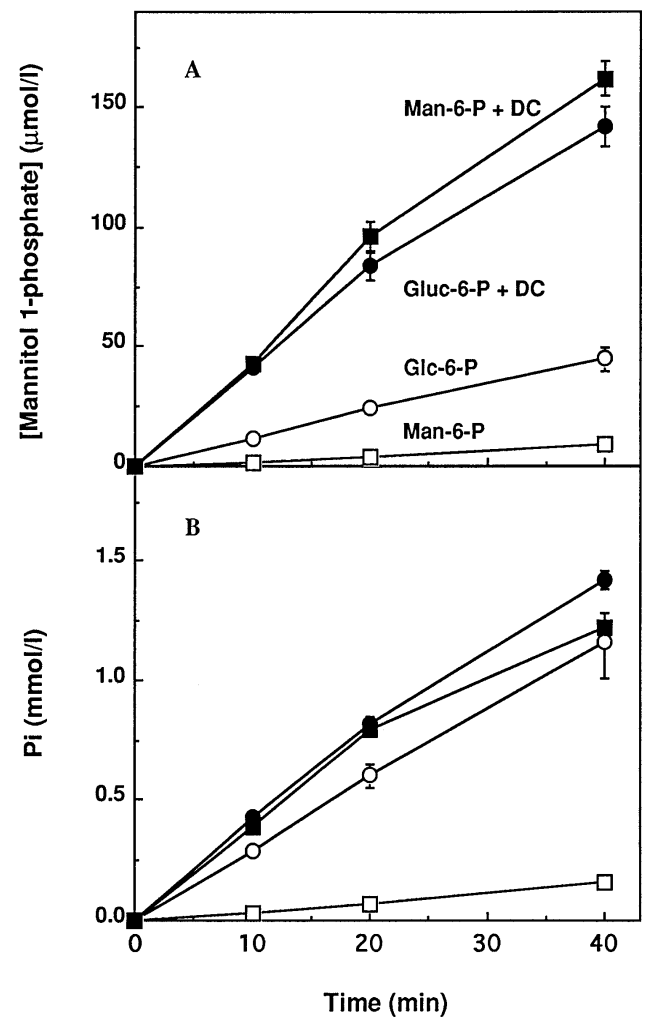

Fig. 8. Effect of deoxycholate on the formation of mannitol 1phosphate (A) and Pi (B) in hepatic microsomes. Liver microsomes were incubated at a final concentration of $1.2 \mathrm{~g}$ protein/1 with $200 \mathrm{mmol} / 1 \mathrm{mannitol}$ and, as indicated, $10 \mathrm{mmol} / \mathrm{l}$ glucose 6-phosphate or mannose 6-phosphate, with or without $1 \mathrm{~g} / \mathrm{l}$ deoxycholate (DC). Results are means \pm SEM for 3 experiments. Values obtained with glucose 6-phosphate and mannose 6-phosphate in the absence of deoxycholate are different $(p<0.05)$

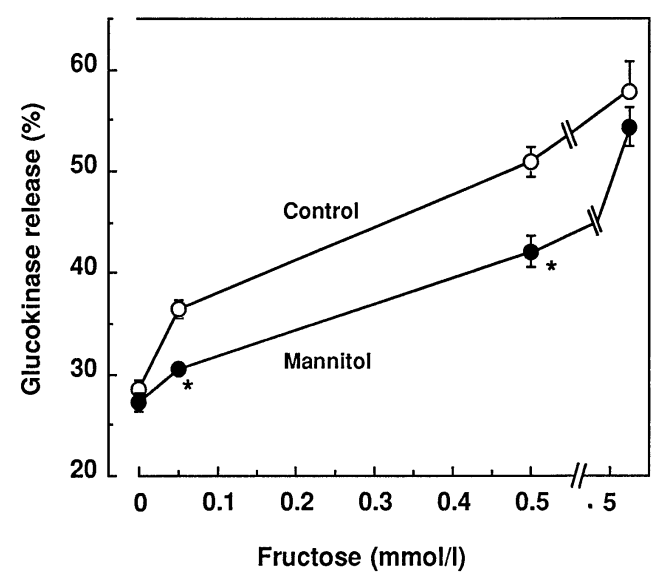

Fig.9. Effect of a preincubation with mannitol on the stimulation of glucokinase translocation by fructose in hepatocytes in primary culture. The cells were seeded and incubated overnight as described previously [12] in minimal essential medium (containing $5.5 \mathrm{mmol} / \mathrm{l}$ glucose) before the addition of $1 \mathrm{mmol} /$ 1 SDI 158. Mannitol (30 mmol/l) and fructose were added at the indicated concentrations 30 and 90 min later. The incubations were arrested $1 \mathrm{~h}$ after the addition of fructose. The results shown are the means \pm SEM for 3 experimental values.

* different from control without mannitol $(p<0.05)$ mannitol 1-phosphate behaved as a competitive inhibitor with a $\mathrm{Ki}$ of $0.06 \mathrm{mmol} / \mathrm{l}$ (not shown).

\section{Discussion}

Due to its prompt conversion to fructose and to fructose 1-phosphate in isolated hepatocytes, sorbitol stimulates the activity of glucokinase and its translocation to the cytosol. This effect is rapid and reaches saturation at concentrations of the polyol in the order of $50 \mu \mathrm{mol} / 1[5,7,8,12]$, reflecting the high activities of sorbitol dehydrogenase and fructokinase, as well as the high sensitivity of the regulatory protein to fructose 1-phosphate.

The effects of mannitol and of sorbitol that we report in this work are slow and require elevated concentrations of the polyols. This is why they could only be observed in the presence of SDI 158, which completely prevents the otherwise rapid conversion of sorbitol (a contaminant of all commercial preparations of mannitol [12]) to fructose 1-phosphate. These effects cannot be attributed to a change in osmolarity, since it was shown previously that $80 \mathrm{mmol} / \mathrm{l}$ galactose, sucrose or trehalose did not affect detritiation in hepatocytes incubated under similar conditions [30]. They are actually the opposite of those of fructose 1-phosphate and can be attributed to mannitol 1-phosphate and sorbitol 6-phosphate, respectively. These two potent analogues of fructose 6-phosphate share with it the property of reinforcing the inhibitory action of the regulatory protein on liver glucokinase, with dissociation constants of 12 and $5 \mu \mathrm{mol} / 1$, respectively, as compared with $20 \mu \mathrm{mol} / \mathrm{l}$ for fructose 6phosphate [23]. If one assumes that fructose 6-phosphate accounts for about $25 \%$ of the hexose 6-phosphates present in hepatocytes, it can be calculated from Table 1 that, in the presence of $60 \mathrm{mmol} / 1 \mathrm{man}$ nitol, the concentration of mannitol 1-phosphate exceeds that of fructose 6-phosphate by about twofold. Mannitol causes therefore a significant increase in the intracellular concentration of compounds with fructose 6-phosphate-like effect, thus promoting the inhibition exerted by the regulatory protein.

Because of the lack of an appropriate methodology, we could not measure the formation of sorbitol 6phosphate in hepatocytes incubated in the presence of sorbitol. Since sorbitol 6-phosphate is, however, a more potent effector of the regulatory protein than mannitol 1-phosphate [23] and since it can be formed by glucose-6-phosphatase almost as rapidly [24], we assume that it mediates the effect of sorbitol on detritiation, which is more pronounced than that of mannitol.

A second target for mannitol 1-phosphate is phosphoglucose isomerase. The concentrations of the polyol-phosphate in cells incubated with 30 or $60 \mathrm{mmol} / \mathrm{l}$ mannitol are of the same order of magni- 
tude as its $\mathrm{Ki}$ for the isomerase. However, the fact that the inhibition of detritiation can be antagonized by fructose or by elevated concentrations of glucose indicates that the inhibition of phosphoglucose isomerase only accounts for part of the effect of mannitol in cells incubated with $5 \mathrm{mmol} /$ glucose. In contrast, the $15-20 \%$ decrease in detritiation observed at saturating concentrations of glucose or fructose is probably completely explained by the inhibition of phosphoglucose isomerase. Measurements using [2$\left.{ }^{3} \mathrm{H}\right]$ galactose [31] indicated that $30 \mathrm{mmol} / \mathrm{l}$ mannitol decreased the extent of detritiation of the glucose 6phosphate pool by about $15 \%$ (Niculescu and Van Schaftingen, unpublished results), in agreement with this interpretation.

The direct relationship observed between the concentrations of mannitol 1-phosphate and hexose 6phosphates under most conditions was an indication that glucose 6-phosphate could be the phosphate donor from which mannitol 1-phosphate is formed. Glucose 6-phosphate was much better than the most common phosphate donor ATP for forming mannitol 1-phosphate in cell-free extracts. Fractionation of the extracts indicated that the implicated enzyme was present in microsomes, the subcellular fraction containing glucose-6-phosphatase [32]. Glucose-6-phosphatase was a good candidate for catalysing such a reaction since it is able to transfer a phosphoryl group not only to water (acting then as a phosphohydrolase) but also to various acceptors (acting then as a phosphotransferase) [24, 33]. The involvement of this enzyme could be further established not only on the basis of the sensitivity of mannitol 1-phosphate formation to vanadate and to preincubation at $\mathrm{pH} 5$ but also on the fact that glucose 6-phosphate was a much better phosphate donor than mannose 6-phosphate in intact microsomes and that it was equally effective as its isomer in detergent-treated microsomes. This last result indicated that the glucose 6-phosphate-dependent formation of mannitol 1-phosphate catalysed by microsomes in the absence of detergent is not contributed by a small portion of disrupted microsomes present in the preparation, but by intact microsomes.

The formation of mannitol 1-phosphate catalysed by glucose 6-phosphatase can account for that observed in isolated hepatocytes. From the rate found in cell-free extracts $\left(0.18 \mu \mathrm{mol} \cdot \mathrm{min}^{-1} \cdot \mathrm{g}\right.$ protein ${ }^{-1}$ protein at $30^{\circ} \mathrm{C}, 10 \mathrm{mmol} / 1$ glucose 6 -phosphate and $200 \mathrm{mmol} / \mathrm{l}$ mannitol) and assuming a $\mathrm{Km}$ of $2 \mathrm{mmol} / \mathrm{l}$ for glucose 6-phosphate and much larger than $200 \mathrm{mmol} / \mathrm{l}$ for mannitol, the calculated rate of mannitol 1-phosphate formation amounts to 12.5 $\mathrm{nmol} \cdot \mathrm{min}^{-1} \cdot \mathrm{g}$ protein ${ }^{-1}$ at $30^{\circ} \mathrm{C}$ in the presence of $0.6 \mathrm{mmol} / 1$ glucose 6 -phosphate and $60 \mathrm{mmol} / \mathrm{l} \mathrm{man}$ nitol. An initial rate of $32 \mathrm{nmol} \cdot \mathrm{min}^{-1} \cdot \mathrm{g}_{\text {protein }}{ }^{-1}$ was actually observed in hepatocytes incubated (at $37^{\circ} \mathrm{C}$ ) with $5 \mathrm{mmol} / \mathrm{l}$ glucose $+20 \mathrm{mmol} / \mathrm{l}$ dihydroxy- acetone (Fig. 6), which contained about $0.6 \mathrm{mmol} / \mathrm{l}$ glucose 6-phosphate (Fig.7). The two rates are in good agreement if one takes into account the effect of temperature.

Glucokinase differs from other hexokinases because it is not inhibited by physiological concentrations of glucose 6-phosphate, the product of the reaction. The discovery of the regulatory protein and of the great reinforcement of its inhibitory effect on glucokinase by fructose 6-phosphate have, however, provided a substitute for this mechanism, since fructose 6-phosphate and glucose 6-phosphate are constantly maintained in equilibrium by phosphoglucose isomerase. Since glucose-6-phosphatase catalyses a reaction which is first-order with respect to its substrate, the glucose/glucose 6-phosphate cycle can be coordinately controlled by the concentration of hexose 6-monophosphates. Thus, when the concentration of these rises as a result of a stimulation of glycogenolysis and gluconeogenesis [34], the stimulation of glucose-6-phosphatase and the inhibition of glucokinase concur to increase net glucose production.

For reasons mentioned in the Introduction, the inhibitory effect of fructose 6-phosphate could not be demonstrated in hepatocytes. The inhibition of glucose detritiation by mannitol 1-phosphate, reported in the present work, is therefore the first proof that glucokinase can be inhibited in hepatocytes by a ligand of the regulatory protein belonging to the group of fructose 6-phosphate analogues.

As mentioned in the Introduction, glucokinase appears to shuttle from the nucleus to the cytoplasm depending on the concentration of fructose 1-phosphate. The implication of the regulatory protein in this phenomenon is essentially based on the nuclear localisation of this protein and on the sensitivity of translocation to fructose 1-phosphate. This role is further substantiated by the finding that the effect of fructose is antagonized by mannitol, since this compound most likely acts via mannitol 1-phosphate, a ligand of the regulatory protein.

Acknowledgements. The authors thank H.G. Hers for helpful criticisms and G. Noël for carrying out most of the experiments presented in this article. This work was supported by the Actions de Recherche Concertées, by the Belgian Federal Service for Scientific, Technical and Cultural Affairs and by the Juvenile Diabetes Foundation International.

\section{References}

1. Matschinsky F (1990) Glucokinase as glucose sensor and metabolic signal generator in pancreatic beta-cells and hepatocytes. Diabetes 39: 647-652

2. Iynedjian, P (1993) Mammalian glucokinase and its gene. Biochem J 293: 1-13

3. Randle PJ (1993) Glucokinase and candidate genes for Type II (non-insulin-dependent) diabetes mellitus. Diabetologia 36: 269-275 
4. Van Schaftingen E, Detheux M, Veiga-da-Cunha M (1994) Short-term control of glucokinase activity. FASEB J 8: 414-419

5. Van Schaftingen E, Vandercammen A (1989) Stimulation of glucose phosphorylation by fructose in isolated rat hepatocytes. Eur J Biochem 179: 173-177

6. Van Schaftingen E (1995) Glucosamine-sensitive and -insensitive detritiation of $\left[2-{ }^{3} \mathrm{H}\right]$ glucose. Biochem $\mathrm{J} 308$ : 23-29

7. Agius L, Peak M (1993) Intracellular binding of glucokinase in hepatocytes and translocation by glucose, fructose and insulin. Biochem J 296: 785-796

8. Agius L (1994) Control of glucokinase translocation in rat hepatocytes by sorbitol and the cytosolic redox state. Biochem J 298: 237-243

9. Toyoda Y, Miwa I, Kamiya M et al. (1994) Nuclear location of the regulatory protein of glucokinase in rat liver and translocation of the regulator to the cytoplasm in response to high glucose. Biochem Biophys Res Commun 204: 252-256

10. Toyoda Y, Miwa I, Satake S, Anai M, Oka Y (1995) Nuclear translocation of the regulatory protein of glucokinase in rat liver and translocation of the regulator to the cytoplasm in response to high glucose. Biochem Biophys Res Com 215: 467-473

11. Brown KS, Kalinowski SS, Megill JR, Durham SK, Mookhtiar KA (1997) Glucokinase regulatory protein may interact with glucokinase in the hepatocyte nucleus. Diabetes 46: $179-186$

12. Niculescu L, Veiga-da-Cunha M, Van Schaftingen E (1997) Investigation on the mechanism by which fructose, hexitols and other compounds regulate the translocation of glucokinase in rat hepatocytes. Biochem J 321: 239-246

13. Agius L, Peak M, Van Schaftingen E (1995) The regulatory protein of glucokinase binds to the hepatocyte matrix but, unlike glucokinase, does not translocate during substrate stimulation. Biochem J 309: 711-713

14. Geisen K, Utz R, Grötsch H, Lang HJ, Nimmesgern $\mathrm{H}$ (1994) Sorbitol-accumulating pyrimidine derivatives. Arzneim-Forsch/Drug Res 44: 1032-1043

15. Klungsøyr L (1966) Purification of the mannitol-1-phosphate dehydrogenase of Escherichia coli. Biochim Biophys Acta 128: 55-62

16. Bartrons R, Hue L, Van Schaftingen E, Hers HG (1983) Hormonal control of fructose 2,6-bisphosphate concentration in isolated rat hepatocytes. Biochem J 214: 829-837

17. Seglen PO (1973) Preparation of rat liver cells. Exp Cell Res 82: 391-398

18. Bontemps F, Hue L, Hers HG (1978) Phosphorylation of glucose in isolated rat hepatocytes. Sigmoidal kinetics explained by the activity of glucokinase alone. Biochem $\mathrm{J}$ 174: 603-611

19. Davies DR, Detheux M, Van Schaftingen E (1990) Fructose 1-phosphate and the regulation of glucokinase activity in isolated hepatocytes. Eur J Biochem 192: 283-289
20. Klungsøyr L (1988) D-mannitol-1-phosphate. In: Bergmeyer HU (ed) Methods of Enzymatic Analysis, 3rd edn. revised, VCH-Verlagsgesellschaft, Weinheim, 6: 276-280

21. Michal G (1988) D-glucose 6-phosphate and D-fructose 6phosphate. In: Bergmeyer HU (ed) Methods of Enzymatic Analysis, $3 \mathrm{~d}$ edn. revised, VCH-Verlagsgesellschaft, Weinheim, 6: 191-198

22. Van Schaftingen E, Opperdoes FR, Hers HG (1987) Effects of various metabolic conditions and of the trivalent arsenical melarsen oxide on the intracellular levels of fructose 2,6-bisphosphate and of glycolytic intermediates in Trypanosoma brucei. Eur J Biochem 166: 653-661

23. Detheux M, Vandercammen A,Van Schaftingen E (1991) Effectors of the regulatory protein acting on liver glucokinase: a kinetic investigation. Eur J Biochem 200: 553-561

24. Stetten MR (1965) Metabolism of inorganic pyrophosphate. III. Acceptor specificity studies with rat liver microsomal pyrophosphate phosphotransferase activity. J Biol Chem 240: 2248-2253

25. Arion WJ, Carlson PW, Wallin BK, Lange AJ (1972) Modifications of hydrolytic and synthetic activities of liver microsomal glucose 6-phosphatase. J Biol Chem 247: 2551-2557

26. Arion WJ, Wallin BK, Lange AJ, Ballas LM (1975) On the involvement of a glucose 6-phosphate transport system in the function of microsomal glucose 6-phosphatase. Mol Cell Biochem 6: 75-83

27. de Duve C, Berthet J, Hers HG, Dupret L (1949) Le système hexose-phosphatasique. Existence d'une glucose-6phosphatase spécifique dans le foie. Bull Soc Chim Biol 31: $1242-1253$

28. Singh J, Nordlie RC, Jorgenson RA (1981) Vanadate: a potent inhibitor of multifunctional glucose-6-phosphatase. Biochim Biophys Acta 678: 477-482

29. Katz J, Rognstad R (1976) Futile cycles in metabolism of glucose. Curr Top Cell Regul 10: 237-289

30. Van Schaftingen E, Vandercammen A (1992) Mechanism of the stimulatory effect of a potassium-rich medium on the phosphorylation of glucose in isolated rat hepatocytes. Eur J Biochem 204: 363-369

31. Katz J, Wals PA, Rognstad R (1978) Glucose phosphorylation, glucose-6-phosphatase, and recycling in rat hepatocytes. J Biol Chem 253: 4530-4536

32. Hers HG, Berthet J, de Duve C (1951) Le système hexosephosphatasique. III. Localisation intracellulaire des ferments par centrifugation fractionnée. Bull Soc Chim Biol 33: $21-41$

33. Hass LF, Byrne WL (1960) The mechanism of glucose-6phosphatase. J Am Chem Soc 82: 947-954

34. Hers HG, Hue L (1983) Gluconeogenesis and related aspects of glycolysis. Ann Rev Biochem 52: 617-653 